\title{
JiSiOU
}

\section{Educating Special Forces Junior Leaders for a Complex Security Environment}

Joint Special Operations University 357 Tully Street Alison Building Hurlburt Field, FL 32544

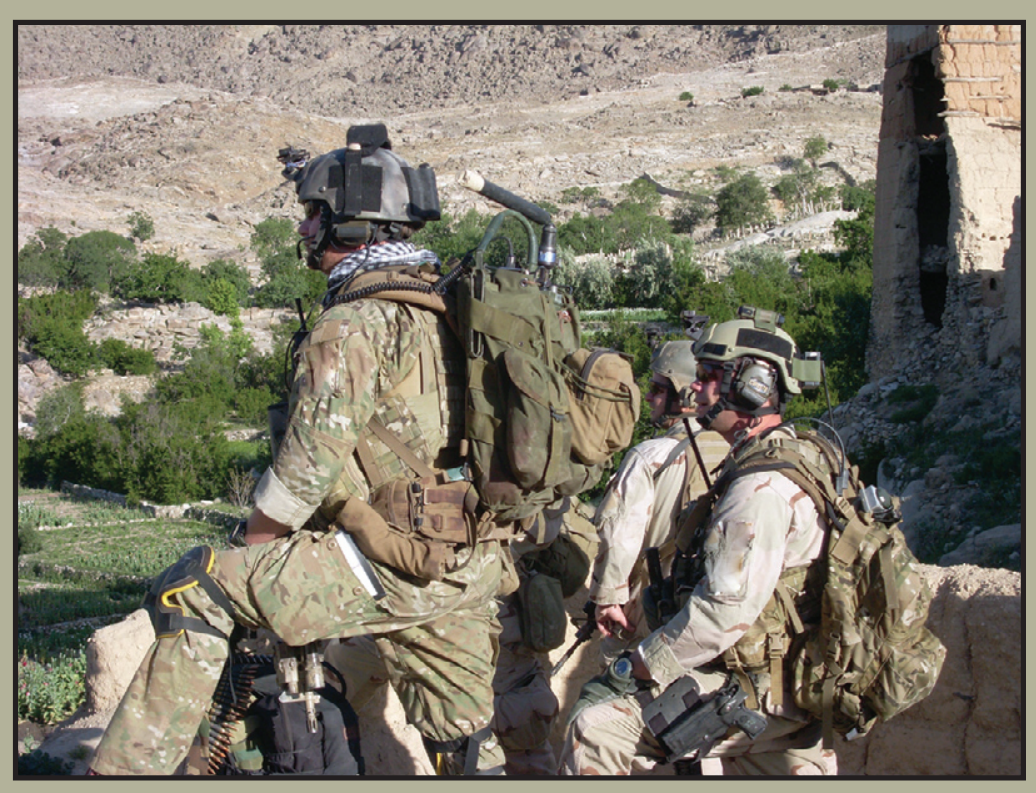




\section{Report Documentation Page}

Form Approved

OMB No. 0704-0188

Public reporting burden for the collection of information is estimated to average 1 hour per response, including the time for reviewing instructions, searching existing data sources, gathering and maintaining the data needed, and completing and reviewing the collection of information. Send comments regarding this burden estimate or any other aspect of this collection of information,

including suggestions for reducing this burden, to Washington Headquarters Services, Directorate for Information Operations and Reports, 1215 Jefferson Davis Highway, Suite 1204, Arlington

VA 22202-4302. Respondents should be aware that notwithstanding any other provision of law, no person shall be subject to a penalty for failing to comply with a collection of information if it

does not display a currently valid OMB control number.

1. REPORT DATE

JUL 2009

4. TITLE AND SUBTITLE

Educating Special Forces Junior Leaders for a Complex Security Environment

6. $\operatorname{AUTHOR}(\mathrm{S})$

7. PERFORMING ORGANIZATION NAME(S) AND ADDRESS(ES)

Joint Special Operations University,357 Tully Street Alison Building,Hurlburt Field,FL,32544

9. SPONSORING/MONITORING AGENCY NAME(S) AND ADDRESS(ES)
3. DATES COVERED

00-00-2009 to 00-00-2009

5a. CONTRACT NUMBER

5b. GRANT NUMBER

5c. PROGRAM ELEMENT NUMBER

5d. PROJECT NUMBER

5e. TASK NUMBER

5f. WORK UNIT NUMBER

8. PERFORMING ORGANIZATION REPORT NUMBER

10. SPONSOR/MONITOR'S ACRONYM(S)

11. SPONSOR/MONITOR'S REPORT NUMBER(S)

12. DISTRIBUTION/AVAILABILITY STATEMENT

Approved for public release; distribution unlimited

13. SUPPLEMENTARY NOTES

14. ABSTRACT

15. SUBJECT TERMS

16. SECURITY CLASSIFICATION OF: a. REPORT

unclassified b. ABSTRACT unclassified c. THIS PAGE

unclassified
17. LIMITATION OF ABSTRACT

Same as

Report (SAR)
18. NUMBER 19a. NAME OF

OF PAGES

52 


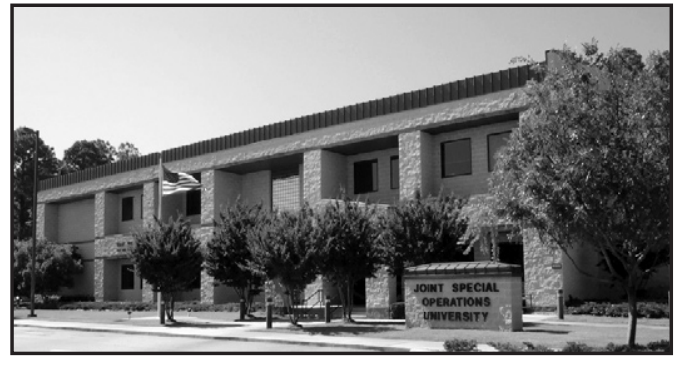

\section{Joint Special Operations University} and the Strategic Studies Department

The Joint Special Operations University (JSOU) provides its publications to contribute toward expanding the body of knowledge about joint special operations. JSOU publications advance the insights and recommendations of national security professionals and the Special Operations Forces (SOF) students and leaders for consideration by the SOF community and defense leadership.

JSOU is the educational component of the United States Special Operations Command (USSOCOM), MacDill Air Force Base, Florida. The JSOU mission is to educate SOF executive, senior, and intermediate leaders and selected other national and international security decision makers, both military and civilian, through teaching, outreach, and research in the science and art of joint special operations. JSOU provides education to the men and women of SOF and to those who enable the SOF mission in a joint and interagency environment.

JSOU conducts research through its Strategic Studies Department where effort centers upon the USSOCOM mission and the commander's priorities.

Mission. Provide fully capable special operations forces to defend the United States and its interests. Plan and synchronize operations against terrorist networks.

Priorities. • Deter, disrupt, and defeat terrorist threats.

- Develop and support our people and their families.

- Sustain and modernize the force.

The Strategic Studies Department also provides teaching and curriculum support to Professional Military Education institutions-the staff colleges and war colleges. It advances SOF strategic influence by its interaction in academic, interagency, and United States military communities.

The JSOU portal is https://jsoupublic.socom.mil.

\section{Joint Special Operations University}

Brian A. Maher, Ed.D., SES, President

Kenneth H. Poole, YC-3, Strategic Studies Department Director

William W. Mendel, Colonel, U.S. Army, Ret.; Jeffrey W. Nelson, Colonel, U.S. Army, Ret.; and William S. Wildrick, Captain, U.S. Navy, Ret - Resident Senior Fellows

\section{Editorial Advisory Board}

John B. Alexander

Ph.D., Education, The Apollinaire Group and JSOU Senior Fellow

Roby C. Barrett, Ph.D., Middle

Eastern \& South Asian History

Public Policy Center Middle East Institute and JSOU Senior Fellow

Joseph D. Celesk

Colonel, U.S. Army, Ret.

JSOU Senior Fellow

Chuck Cunningham

Lieutenant General, U.S. Air Force, Ret.

Professor of Strategy, Joint Advanced

Warfighting School and JSOU Associate Fellow

Gilbert E. Doan

Major, U.S. Army, Ret., JSOU

Institutional Integration Division Chief

Brian H. Greenshields

Colonel, U.S. Air Force

SOF Chair, Naval Postgraduate School

Thomas H. Henriksen

Ph.D., History, Hoover Institution

Stanford University and ISOU Senior Fellow

Russell D. Howard

Brigadier General, U.S. Army, Ret.

Faculty Associate, Defense Critical Language/

Culture Program, Mansfield Center, University

of Montana and JSOU Senior Fellow

John D. Jogerst

Colonel, U.S. Air Force, Ret.

18th USAF Special Operations Schoo

Commandant

James Kiras

Ph.D., History, School of Advanced Air and

Space Studies, Air University and ISOU

Associate Fellow
Alvaro de Souza Pinheiro

Major General, Brazilian Army, Ret. ISOU Associate Fellow

James F. Powers, Jr.

Colonel, U.S. Army, Ret.

Director of Homeland Security,

Commonwealth of Pennsylvania and

ISOU Associate Fellow

Richard H. Shultz, Jr

Ph.D., Political Science

Director, International Security

Studies Program, The Fletcher School, Tufts

University and JSOU Senior Fellow

Stephen Sloan

Ph.D., Comparative Politics

University of Central Florida

Robert G. Spulak, Jr.

Ph.D., Physics/Nuclear Engineering

Sandia National Laboratories

and JSOU Associate Fellow

Joseph S. Stringham

Brigadier General, U.S. Army, Ret.

Alutiiq, LLC and ISOU Associate Fellow

Graham H. Turbiville, Jr.

Ph.D., History, Courage Services, Inc. and JSOU Senior Fellow

Jessica Glicken Turnley

Ph.D., Cultural Anthropology/

Southeast Asian Studies

Galisteo Consulting Group and JSOU Senior Fellow

Rich Yarger

Ph.D., History, Professor of National

Security Policy, U.S. Army War College and JSOU Associate Fellow 
On the cover. Capt Kyle Walton, detachment commander, with other members of Operational Detachment Alpha 3336 of the 3rd Special Forces Group (Airborne) on a recon of the remote Shok Valley of Afghanistan where they fought an almost 7-hour battle with terrorists in a remote mountainside village. Ten detachment members received the Silver Star for heroism during that action. Photo by Sgt David N. Gunn on 15 December 2008. 



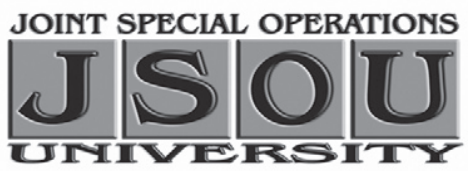

\section{Educating Special \\ Forces Junior Leaders \\ for a Complex Security \\ Environment}

Russell D. Howard

JSOU Report 09-6 The JSOU Press Hurlburt Field, Florida 
Comments about this publication are invited and should be forwarded to Director, Strategic Studies Department, Joint Special Operations University, 357 Tully Street, Alison Building, Hurlburt Field, Florida 32544. Copies of this publication may be obtained by calling JSOU at 850-884-1569; FAX 850-884-3917.

The JSOU Strategic Studies Department is currently accepting written works relevant to special operations for potential publication. For more information please contact Mr. Jim Anderson, JSOU Director of Research, at 850-884-1569, DSN 579-1569, james.d.anderson@hurlburt.af.mil. Thank you for your interest in the JSOU Press.

This work was cleared for public release; distribution is unlimited.

ISBN 1-933749-36-9 
The views expressed in this publication are entirely those of the author and do not necessarily reflect the views, policy or position of the United States Government, Department of Defense, United States Special Operations Command, or the Joint Special Operations University. 
Recent Publications of the JSOU Press

Hunting Leadership Targets in Counterinsurgency and Counterterrorist Operations, June 2007, Graham H. Turbiville, Jr.

Executive Report, JSOU Second Annual Symposium (30 April-3 May 2007)

A Theory of Special Operations, October 2007, Robert G. Spulak, Jr.

Block by Block: Civic Action in the Battle of Baghdad, November 2007, Adrian T. Bogart III

Private Security Infrastructure Abroad, November 2007, Graham H. Turbiville, Jr.

Intelligence in Denied Areas, December 2007, Russell D. Howard Is Leaving the Middle East a Viable Option, January 2008, Thomas H. Henriksen

Retaining a Precarious Value as Special Operations Go Mainstream, February 2008, Jessica Glicken Turnley

Disrupting Threat Finances, April 2008, Wesley J.L. Anderson

USSOCOM Research Topics 2009

India's Northeast: The Frontier in Ferment, September 2008, Prakash Singh

What Really Happened in Northern Ireland's Counterinsurgency, October 2008, Thomas H. Henriksen

Guerrilla Counterintelligence: Insurgent Approaches to Neutralizing Adversary Intelligence Operations, January 2009, Graham H. Turbiville, Jr.

Policing and Law Enforcement in COIN - the Thick Blue Line, February 2009, Joseph D. Celeski

Contemporary Security Challenges: Irregular Warfare and Indirect Approaches, February 2009, Richard D. Newton, Travis L. Homiak, Kelly H. Smith, Isaac J. Peltier, and D. Jonathan White

Special Operations Forces Interagency Counterterrorism Reference Manual, March 2009

The Arabian Gulf and Security Policy: The Past as Present, the Present as Future, April 2009, Roby C. Barrett

Africa: Irregular Warfare on the Dark Continent, May 2009, John B. Alexander

USSOCOM Research Topics 2010

Report of Proceedings, 4th Annual Sovereign Challenge Conference (16-19 March 2009)

Information Warfare: Assuring Digital Intelligence Collection, July 2009, William G. Perry 


\section{Foreword}

T $\mathrm{n}$ this paper, Brigadier General (Ret.) Howard argues for graduate level education for the junior leaders of our Special Forces (SF). By exploring the SOF future strategic environment that includes globalization, demographic trends, competition for resources, transnational nonstate actors, advanced technology, and emerging powers Brigadier General Howard identifies "cultural competency" as critical to the development of junior SF officers. The need for the SF operator, at once, to effectively interact with indigenous peoples, interagency counterparts, and transnational, nongovernmental players suggests that a new program of graduate level study is needed early-on in the officer's career.

By Howard's analysis, such graduate programs should focus on developing one's intellectual capacity to synthesize information concerning areas such as interagency relationships, language proficiency, cultural, socialpolitical anthropology, negotiation, and cross-cultural communications. So educated, the junior SF officer is enabled to adapt and apply his intellectual prowess to confront the daily challenges he will certainly face in the field. General Downing stated that SF officers are "the senior U.S. representative and implementer of U.S. foreign policy" ... "out there." Howard suggests that programs at Naval Post Graduate School and other traditional graduate programs do not educate junior SF officers because those students are typically majors (O-4s) that move on to senior positions after graduate school. Howard argues, earlier educational opportunities should be available to the junior SF O-3s - this is where additional graduate level effort is needed.

Brigadier General Howard does not pretend to solve the operation tempo (OPTEMPO) problem caused by normal career development and the nearly continuous deployment of SF personnel to two wars. These are key reasons for what he identifies as equity issues or an opportunity gap, whereby conventional officers seem to have greater opportunities than SF counterparts to attend graduate school. To close this opportunity gap, Howard argues for a graduate program formula that is distant-learning intensive, has an emphasis on operational skills first, strategic skills last, and takes 5 years to complete. Such programs might extend the time window for an SF officer's participation in graduate level education and as the author suggests "front load" education. In sum, this paper advances the concept of educating SF 
officers early in their careers so they can apply their knowledge working through, by, and with indigenous counterparts in the irregular warfare environment. Although Brigadier General Howard limited his study to consider SF officers, it has relevance and application to the warrant officer grades and other junior officers across all USSOCOM components.

Kenneth H. Poole, YC-3

Director, JSOU Strategic Studies Department 


\section{About the Author}

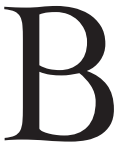

rigadier General (Ret.) Howard is a faculty associate at the Mansfield Center, University of Montana. He was the founding director of The Jebsen Center for Counter-Terrorism Studies at The Fletcher School, Tufts University. Prior to assuming the Tufts responsibilities, he was the Social Sciences Department chair and the founding director of the Combating Terrorism Center at West Point.

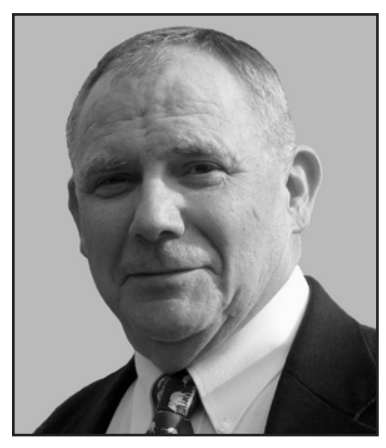

His previous Army positions include chief of staff fellow at the Center for International Affairs, Harvard University and commander of the 1st Special Forces Group (Airborne), Fort Lewis, Washington. Other recent assignments include assistant to the Special Representative to the Secretary General during United Nations Operations in Somalia (UNOSOM) II, deputy chief of staff for I Corps, and chief of staff and deputy commander for the Combined Joint Task Force, Haiti/Haitian Advisory Group. Previously, he was commander of 3rd Battalion, 1st Special Warfare Training Group (Airborne) at Fort Bragg, North Carolina. He also served as the administrative assistant to Admiral Stansfield Turner and as a special assistant to the commander of SOUTHCOM.

As a newly commissioned officer, he served as an "A" team commander in the 7th Special Forces Group from 1970 to 1972. He left the active component and then served in the U.S. Army Reserve from 1972 to 1980. During this period he served as an overseas manager, American International Underwriters, Melbourne, Australia and China tour manager for Canadian Pacific Airlines. He was recalled to active duty in 1980 and served initially in Korea as an infantry company commander. Subsequent assignments included classified project officer, U.S. Army 1st Special Operations Command, at Fort Bragg, and operations officer and company commander, 1st Battalion, 1st Special Forces Group in Okinawa, Japan.

General Howard has a B.S. in Industrial Management from San Jose State University and B.A. in Asian Studies from the University of Maryland. He also has a M.A. in International Management from the Monterey Institute of International Studies and MPA from Harvard University. He was an 
assistant professor of Social Sciences at the U.S. Military Academy and a senior service college fellow at The Fletcher School of Law and Diplomacy, Tufts University. He is a JSOU senior fellow, and his previous JSOU publication is Intelligence in Denied Spaces: New Concepts for a Changing Security Environment (December 2007). 


\section{Educating Special Forces Junior Leaders for a Complex Security Environment}

\section{Introduction}

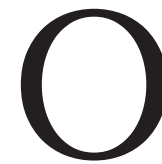

riginally, this project was intended to review the education requirements and opportunities available to all Special Operations Forces (SOF) officers during a normal career path. The focus was to be on field-grade opportunities at service schools, civilian education opportunities (including graduate school), international education (such as opportunities for studying abroad), and service with industry. A prime objective was to ascertain whether the current Special Operations Officer Professional Education program provides the knowledge, understanding, and competencies to prepare officers for leadership in a future security environment characterized by continued terrorist activity, insurgency, and other forms of irregular warfare.

The actual study does both less and more than its original premise. Instead of focusing on the entire special operations officer community (Army, Navy, Air Force, and Marines) and at all levels (O-3 through O-6), this study concentrates on U.S. Army Special Forces officers, particularly captains and majors. Certainly, a comprehensive look at special operations officer education is warranted and important, but well beyond the scope of this study and the author's resources. Perhaps the results of this work will prompt others to conduct similar research for higher ranks and other services in the SOF community.

While the original target research group was too large, the operational environment as initially defined (terrorism, insurgency, and other forms of irregular warfare) was much too limited. In truth, the operational environment all SOF officers will face in the coming decades will include much more 
than irregular warfare, which greatly complicates the training and education requirements for the entire officer corps, but particularly for Special Forces officers.

This study contains six parts:

a. List of assumptions that will impact Special Forces officer education and training

b. Best guess at what the "future international security environment" will look like

c. Recommendations-based on the assumptions and the "future operational environment"-of several knowledge-based education competencies-some familiar, some not

d. Survey of graduate programs teaching these competencies

e. Statistical analysis and discussion of the "gap" in graduate education between Army Special Forces and non-Special Forces

f. Suggestions for providing Special Forces officers with a viable, tailored, and quality master's degree that will enhance their operational performance, accelerate their capability for senior-level and joint staff billets, and increase their opportunity for successful command in increasingly difficult command situations.

\section{Assumptions}

Assumptions describe the facts about circumstances believed to be true or beliefs that are thought to be broadly shared. These assumptions are based on several years of teaching the course "National Security Strategy" at the United States Military Academy, West Point and of researching four published books on the topic of terrorism. The author believes these assumptions to be true, and further, that a broad coalition of academics, operators, and policymakers also agree. These assumptions were initially briefed as part of a presentation at the International Special Operations Forces (ISOF) week in Tampa, Florida in May 2008, where they were favorably received. From these assumptions and the following "future international security environment," the author has formulated recommendations regarding future education requirements. The assumptions follow:

a. The next U.S. presidential administration will have little enthusiasm for major conventional military operations. 
b. The United States Special Operations Command (USSOCOM) will be the "go-to" command for the full spectrum of security challengesfrom state-centric to transnational nonstate actor, from conventional to criminal, and everything in between.

c. The next administration and administrations well into the 21st century will face increased terrorist, armed group, irregular warfare, and international criminal activity. Transnational nonstate actors will be the United States primary adversaries.

d. At the same time, however, the next administration could also face increased state-related conflict from Iran, Russia, Venezuela, and perhaps (though unlikely) China.

e. Interagency operations will be as important as interservice operations for SOF.

f. Ungoverned territories in failed and failing states will be frequent operational areas for SOF.

g. Africa, the Caucasus, the Balkans, the Middle East, Central Asia, South Asia, and Southeast Asia-the so called arch of instability - will dominate the SOF agenda for the next decade.

h. International SOF forces, particularly from former Soviet Union and Warsaw Pact nations, will become as important (and perhaps more so) than traditional North Atlantic Treaty Organization (NATO) SOF.

\section{The Future Strategic Environment}

It's tough to make predictions, especially about the future.

- Yogi Berra

Many attempt to predict the future; some get it right and some do not. No better example of this is a recent post from Harvard Business Publishing's blog: "Will Your Company Predict the Future Like GM or Like Toyota?" The post explains how GM failed to predict rising oil prices and continued to make large gas-guzzling trucks and large cars, while Toyota did the opposite. Because of the companies' different predictions, Toyota has overtaken GM as the world's largest auto manufacturer.

Predicting the future security environment is a difficult but extremely important task for political leaders, defense planners, and the American public. Getting it right ensures comprehensive security at affordable costs. 
Getting it wrong could be catastrophic. The truth is, predicting the future security environment has never been more important, nor has it been more difficult. The task has perhaps never been more important because the Clinton and Bush administrations' predictions have been more analogous to GM's than Toyota's. Moreover, continued forecasting based on Cold War paradigms has been incorrect and counterproductive, making prediction more difficult because the international security environment is multifaceted, in flux, and not responsive to traditional diplomatic negotiations and/ or conventional military power.

Numerous "predictive" studies have been initiated to help policymakers and planners address emerging security challenges. ${ }^{2}$ Perhaps the best predictive analysis is a yet-to-be published article by Major Paul Oh, a professor at the Department of Social Sciences at the U.S. Military Academy. Entitled "Future Strategic Environment in an Era of Persistent Conflict," it was the thought piece for a conference held at West Point in June 2008. ${ }^{3}$ Major Oh surveyed most of the above-referenced predictive studies and other documents for his work, which is well documented, comprehensive, interesting, and in this author's opinion, just about the best "future strategic analysis" on the street.

Major Oh identifies the primary trends affecting the future security environment as "globalization, demographics, environment and competition for resources, nonstate actors and challenge to governance, advances in technology, and the rise of emerging powers." ${ }^{4}$ Each of these concepts is outlined in more detail below.

\section{Globalization}

Oh refers to globalization as "the good, the bad and the ugly." In the good, Oh predicts that greater market integration will benefit the world economy, and globalization will be the engine for greater economic growth, resulting in many in the world rising out of poverty. He notes that "the global economy is expected to be 80 percent larger in 2020 than in 2000," and average per capita income to increase by 50 percent. ${ }^{5}$ Emerging economies such as India and China will continue to grow, with both examples tripling their Gross Domestic Product (GDP) by 2025, and the percentage of those living in extreme poverty will decline. ${ }^{6}$ 
The bad is the economic disparity between those states that thrive in a globalized world and those that do not-or, as Oh states, "the benefits of globalization will not be global." 7 There will be winners and losers, and the losers will be concentrated in areas along the "arc of instability," a "swath of territory running from the Caribbean Basin through most of Africa, the Middle East, and Central and Southeast Asia." 8 Although absolute worldwide poverty is declining, one half of the world's population-roughly 3 billion people-live on less than $\$ 2$ a day, ${ }^{9}$ and more than 300 million The resulting disparities are evident to all ... people live on less than $\$ 1$ a day in sub-Saharan Africa. ${ }^{10}$ The resulting disparities are evident to all because of the Internet and other globalized communication media.

Many believe that globalization, either separately or in conjunction with religious extremism, is a root cause of terrorism - the ugly in this equation. According to some, those who have not reaped the rewards of globalization worry that unbridled development and change can exploit workers and replace ancient cultures with McDonald's and Mickey Mouse. ${ }^{11}$ They concur that globalization is based on the American economic system, and because the U.S. is the dominant world power, it has succeeded in expanding the reach of its version of globalization to more and more areas of the world. However, the gap between the rich and poor in most countries has grown wider during the last 20 years of U.S.-led globalization. As a result, animosities-which spawn terrorist acts against America-have grown "as the poor have watched American wealth and hegemony expand, while they themselves have received scarcely any benefit." 12 Populations perceiving themselves as disenfranchised will most certainly be breeding grounds for extremists and other criminal elements who want their fair share. ${ }^{13}$

Globalization and greater interdependence make the nation-state and geographic borders less important and less effective. Terrorists (particularly the transnational nonstate actor variety), weapons of mass destruction, and infectious diseases such as AIDS, Severe Acute Respiratory Syndrome (SARS), and Avian Flu do not recognize or respect borders. Indeed, greater interconnectivity and more travel options enable ugliness in many formsdisease, terrorism, criminal cartels - to spread throughout the world at a frightening pace. 


\section{Demographic Trends}

Demographic trends, such as population growth and decline, do not bode well for international stability. The world's population will grow nearly 25 percent between now and 2025, but most of that growth will be in the developing world. In fact, developed nations such as Japan, Russia, and many European states will see declining and aging populations in the next two decades. For example, Japan's population will decrease by 4 million in the next decade, while its ratio of employment-age citizens (15 to 65) to retired over 65 will be only two to one by $2025 .{ }^{14}$ In contrast, population growth in sub-Saharan Africa (43 to 48 percent), the Middle East (38 percent), Latin America (24 percent), and Asia (21 percent) $)^{15}$ will tax already struggling economies and social support systems. To put this growth in perspective, "nine out of ten people will be living in the developing world in the next 20 years." 16

Unlike the aging population trends in the developing world, "about 59 percent of the population of sub-Saharan Africa will be under 24 years by 2025," and the working-age population in the Middle East and North Africa "will expand by 50 and 40 percent respectively." ${ }^{17}$ From a historical perspective, this is a disaster in the making. This bulging youth population in the developing world will challenge governments to provide education and employment opportunities, "setting up the potential for violent conflict." 18 As a recent Economist article notes, youth "without either jobs or prospects" will trade "urban for rural poverty, head for the slums, bringing their anger and machetes with them." ${ }^{19}$ In fact, "in the last two decades, 80 percent of all civil conflicts took place in countries where 60 percent or more of the population was under 30 years of age." 20

\section{Environment and Competition for Resources}

Many experts believe climate change and the competition for resources could have far-reaching security implications. ${ }^{21}$ The author takes no stand on the global-warming debate in this paper, but does agree with others that a "decline in water supplies for drinking and irrigation, a decline in agricultural productivity as a result of changes in rainfall, temperature and pest patterns, and large economic and human losses attributable to extreme weather events will all take their toll" on many specific geographical regions and will affect the global system as a whole. ${ }^{22}$ A good example is the Sahel 
region of Africa, where the desert has been encroaching southward more than 3 kilometers a year, ${ }^{23}$ and rainfall in the area has declined by up to 30 percent in the last 40 years. The potential for conflict over disappearing pasture and evaporating water holes is huge. The southern Nuba tribe has warned it might restart the half-century war between North and South Sudan because "Arab nomads-pushed southward into their territory by drought-are cutting down trees to feed their camels." ${ }^{24}$ Interestingly, for those who served in Somalia, this is a common theme. There, much of the conflict was the result of nomadic tribes encroaching on pastoralist and agriculturalist tribes' territory. ${ }^{25}$

Exacerbating environmental concerns is the ever-increasing competition for many resources, not just productive land. In the next several decades, the demand for natural resources will greatly increase as nations modernize and states such as India and China grow, prosper, and-as discussed later in this paper-attempt to achieve world-power status. Demand for energy and In the next several decades, the demand for natural resources will greatly increase... water will be of particular concern. For example, demand for energy will likely grow by more than 50 percent by 2035, with fossil fuels projected to meet 80 percent of this increase ${ }^{26}$ and global consumption of natural gas to increase by 87 percent. ${ }^{27}$ China and India's oil consumption has already had a major effect on global oil prices. If projections are correct-indicating China will have to increase consumption by 150 percent and India by 100 percent by 2020 to maintain current growthimagine the strain on gas prices at the pump over the next decade. ${ }^{28}$

The competition for fossil fuels will intensify as the U.S., China, India, and other major economies vie to secure long-term energy supplies, "making it even more difficult for developing nations to afford minimal energy for their [increasing] populations." ${ }^{29}$ The quest for oil reserves has security implications as "have" nations compete for oil in the Middle East and Africa along the "arc of instability" and "have-not" nations face economic peril because of rising fuel costs.

In addition to oil, water and food have future security and instability implications. In fact, two experts contend that water and resulting food shortages are far more serious than depleted oil reserves. Dr. Alan Dupont of Strategic and Defence Studies, Australian National University "says water has overtaken oil as the world's most critical and diminishing resource." ${ }^{30}$ 
According to Dupont, one third of the world's population does not have enough water today; by 2020, two thirds of the population will not have enough water; and within 25 years, 7 billion people could suffer from water scarcity. ${ }^{31}$

Dupont is not the only scholar to express concern about impending water shortages. "There are substitutes for oil, but there are no substitutes for water," says Lester Brown, author of the book Outgrowing the Earth: The Food Security Challenge in an Age of Falling Water Tables and Rising Temperature. ${ }^{32}$ As the title implies, Brown contends that falling water tables and rising temperatures are making it more difficult for the world's farmers to produce enough food for the 76 million people added to the world population each year..$^{33}$ According to Brown, "Many Americans see terrorism as the principal threat to security but for much of humanity, the effect of water shortages and rising temperatures on food security are far more important issues." ${ }^{4}$ Brown states, "for the 3 billion people who live on $\$ 2$ a day or less and who spend up to 70 percent of their income on food, even a modest rise in food prices can quickly become life-threatening. For them it is the next meal that is the overriding concern." ${ }^{35}$

\section{Transnational Nonstate Actors}

During the next two decades, nonstate actors, not states, will be the primary security threat to the U.S. and Western allies. Nonstate actors such as Al Qaeda, who owe no allegiance to a state and are not bound by national boundaries, are likely to continue to grow in strength and lethality. ${ }^{36}$ Small, empowered groups such as terrorists, insurgents, and criminal cartels will be increasingly able to challenge states as states' past monopoly on information and destructive power diminishes. ${ }^{37}$ This is problematic because the traditional forms of state interaction-diplomatic, economic, and militaryto solve differences prior to conflict are difficult to apply with a nonstate actor. When things get dicey, with whom do you negotiate, on whom do you impose sanctions, and whom do you threaten with force? And if a transnational, nonstate actor like Al Qaeda uses a weapon of mass destruction against a state, how does a state properly retaliate? ${ }^{38}$

Links between nonstate actors such as terrorists and criminals, which capitalize on gaps in law enforcement and weak security structures, are increasingly becoming the norm in today's transnational environment. ${ }^{39}$ The strategic alliance between terrorism and crime ${ }^{40}$ - effectively described as a 
"terror-crime nexus"- takes advantage of transnational networks, allowing illicit actors to transcend traditional or regional spheres of influence. In some corners of the globe lacking strong central authority, both terrorism and crime become a "means of making war without declaring it." ${ }^{41}$ Criminal and terrorist networks thrive and support situations of "low-intensity" conflict, which are further exacerbated by the power vacuum that exists in international law enforcement. As a result, populations in areas where these groups are active become increasingly impoverished and subject to conflict, while few actually benefit from the illicit activities. The negative international and local effects of transnational crime and terror reveal that the nexus between these activities is a global threat affecting governments and populations at all levels. ${ }^{42}$

\section{Advanced Technology}

Advances in technology are a double-edged sword. Increased computing capacity combined with advances in nanotechnology, robotics, genomics, and biotechnology will improve the ability of governments to deal with society's daunting medical, nutrition, environmental, transportation, and a host of other future concerns. However, the availability and ease of technology transfer allow broad access to these technologies to those who would use them to do great harm. Technological advances and underground trafficking by the terror-crime nexus make weapons of mass destruction (WMDnuclear, chemical, biological, and radiological) ever easier for terrorists to acquire. ${ }^{43}$ Experts have begun to recognize the growing role of networksspecifically, advanced networked organizational designs and related doctrines, strategies, and technologies among terrorist practitioners and other nefarious transnational, nonstate actor groups. According to several experts, "The growth of these networks is related to the spread of advanced information technologies that allow dispersed groups, and individuals, to conspire and coordinate across considerable distances." 44

\section{Emerging Powers}

America's superpower status could be contested in coming decades by a more forceful Russia (which has attacked Georgia), and emerging economic powerhouses such as India and China. Russia maintains a substantial nuclear force and a sizeable military and continues to develop modern weaponry. The country also has vast reserves of natural resources and is 
a leading producer and exporter of minerals, gold, timber, oil, and natural gas, with Siberia and the Russian Far East particularly rich in natural resources. ${ }^{45}$ However, despite the abundance of resources, Russia has serious problems, including a declining and aging population, troubled frontiers, and its remaining mineral and fossil fuel wealth located in its difficult to develop eastern terrain. ${ }^{46}$ More importantly, it is difficult to consider Russia a "superpower" when its GDP is about the size of New Jersey's. ${ }^{47}$

India is a regional power now and could be a global power in the future. Many predict that India will surpass China as the world's most populous country in $2030 .{ }^{48}$ India's middle class numbers more than 200 million (four times the size of France's total population), and economic growth has been steady. ${ }^{49}$ More importantly, India is a nuclear power that has embarked on an aggressive military modernization plan relying heavily on purchasing modern Russian submarines, tanks, and aircraft. ${ }^{50}$ Still, obstacles to India achieving super or even major power status remain. In an article entitled, "India the Superpower? Think Again," Cait Murphy of Fortune Magazine gives several reasons why:

a. Of the Indian children under the age of five, 47 percent are either malnourished or stunted.

b. The adult literacy rate is 61 percent (behind Rwanda and barely ahead of Sudan).

c. Only 10 percent of the entire Indian labor force works in the formal economy; of these, fewer than half are in the private sector.

d. The enrollment of 6-to-15-year-olds in school has actually declined in the last year.

e. About one fifth of the population is chronically hungry; about half of the world's hungry live in India.

f. More than a quarter of the India population lives on less than $\$ 1$ a day.

g. India has more people with HIV than any other country. ${ }^{51}$

Russia and India have serious internal structural problems that will inhibit their ability to attain world power status. India and Russia will be regional powers that could challenge the U.S. within their respective regions, but they will likely not be able to challenge the U.S. globally.

China is a different story. A recent Pew Poll reveals that at least substantial percentages of people interviewed internationally believe China will 
replace the U.S. as the world's superpower, and some believe China already has. According to the Pew Research Center:

While no country currently believes China has already overtaken the U.S. as the world's dominant power, large percentages in most countries-and even majorities in some, including a 53 percent majority of Chinese-believe China eventually will do so in the future. Most of those surveyed in Germany, Spain, France, Britain, and Australia think China either has already replaced the U.S. or will do so in the future. Even in the U.S. more than one in three say China either has already overtaken their country (5 percent) or will eventually do so (31 percent), although a 54 percent majority doubts China will ever unseat the U.S. The Japanese (67 percent) are the most confident China will never replace the U.S. ${ }^{52}$

In September 1999, the author of this monograph published a paper entitled "The Chinese People's Liberation Army: 'Short Arms and Slow Legs." It predicted that China's goal of becoming a genuine power and regional hegemon in the new century seems quite likely, but it remains a distant goal to be achieved perhaps in the middle of the century. ${ }^{53}$ Today, the situation may be more nuanced. The paper was principally about military power and in that regard, and the author still believes the prediction to be valid. True, the People's Liberation Army (PLA), Navy (PLAN), and Air Force (PLAA) have enjoyed double-digit budget increases every year since 1997, and the acquisition of modern Russian arms has advanced their capabilities significantly since 1999. Many of these weapons appear to have the primary purpose of deterring possible U.S. intervention in a Taiwan crisis, but some significantly expand the Chinese military's ability to project power regionally ${ }^{54}$ According to the paper, these include development of more accurate short-range and medium-range conventional ballistic missiles, acquisition of Kilo-class submarines and Sovremenny destroyers, deployment of tankers and air-refueling technology to extend the range of fighters, and efforts to improve airlift and sealift capabilities. ${ }^{55}$

Still, China has a long way to go to achieve military parity with the U.S. For example, some reports note that Chinese military officials are now discussing building an aircraft carrier. ${ }^{56}$ Actually, this is something Chinese naval officers began to discuss in the late 1970s, and in 1998 they bought two Soviet carriers. However, neither was put to sea; instead, they were used as 
floating military-themed amusement parks. Some analysts think China might have a single aircraft carrier by 2015 , but others, including this author, believe it will not have one until 2020 or later. ${ }^{57}$

Clearly, the Chinese continue to invest in a robust military modernization program. Last year the military budget rose 17.8 percent-the tenth straight year of double-digit increases ${ }^{58}$ China officially says their defense budget is close to $\$ 60$ billion; in truth, because of purchasing power parity and other accounting procedures, the actual figure is probably closer to $\$ 100$ billion. Still, compared to the U.S. figure of more than $\$ 600$ billion, the Chinese are not in the same league militarily with the United States and will not challenge the U.S. militarily or achieve superpower status for another three or four decades.

In addition to military power, however, economic power and diplomatic power are measures of superpower potential, and in both, China is surging. Indeed, China's large and growing economy, skillful diplomacy, and military restraint have enabled the nation to significantly expand its global influence, particularly in the developing world. ${ }^{59}$ Large-scale financial and technical assistance for infrastructure projects, particularly in poorer countries with natural resources are a form of commercial diplomacy that has been particularly effective in gaining influence and friends in the United Nations. Nowhere is this more true than in Africa, where China is investing huge sums throughout the continent.

The main driver of China's interest in Africa is to secure energy and resource assets. ${ }^{60}$ In order to hedge against rising commodity prices and possibly long-run supply shortages, the Chinese government encourages Chinese companies to secure a wide range of commodity assets by out bidding other foreign companies in securing these assets. ${ }^{61}$ The primary countries in China's broader African engagement are the resource-rich Angola, Sudan, Nigeria, Zambia, and the Democratic Republic of Congo (DRC) as well as the more politically strategic countries of South Africa, Ethiopia, and Egypt. ${ }^{62}$ However, smaller African countries with comparatively little economic or political significance-Ghana, for example-have received relatively large aid and investment support from China. ${ }^{63}$

China's commercial-diplomacy approach in Africa could be a source of conflict with the U.S. in the region. Countries whose political systems have been sharply criticized by the U.S., such as Sudan and Zimbabwe, have found a new ally in China, which asks few questions about political freedom or 
human rights. ${ }^{64}$ China, which purchases most of Sudan's oil, fielded accusations of selling the Sudanese government military equipment and training Sudanese pilots for missions in Darfur. ${ }^{65}$ These alleged actions violate a UN arms embargo that "requires foreign nations to take measures to ensure they do not militarily assist anyone in the conflict in Darfur, in which the UN estimates that about 300,000 people have died." ${ }^{66}$ The terms of the embargo, says international lawyer Clare de Silva, "cover not only just the supply of weapons, military vehicles, [and] paramilitary equipment. It also covers training any technical assistance, so the training of pilots obviously falls within the scope of the embargo." ${ }^{67}$

China responds to such allegations by noting it is but one of several countries that sell weapons to Sudan and "is by no means the biggest exporter." ${ }^{8}$ According to Liu Guijin, China's Foreign Minister, China has expressed "grave concerns" to the Sudanese government about the violence in Darfur and is working to reduce tensions in Sudan's western province. ${ }^{69}$ However, given the economic clout that China has in Sudan, many conclude that China could be much more influential in getting the Sudan to resolve the Darfur conflict, and China's behavior there is indicative of a foreign policy that may be "confrontational" and counter to U.S. interests.

The key concepts brought forward by Major Oh's excellent predictive analysis, as well as other such documents, illustrate the importance of developing a comprehensive understanding of the world. Focusing on the concepts of globalization, demographics, environment, nonstate actors, technology, and the rise of emerging global powers through a multidisciplinary lens would allow Special Forces officers-or any U.S. government employee involved in policy formulation and implementation-to make more informed and nuanced decisions.

\section{Education Competencies}

Officers assessed into Special Forces are mostly junior captains or promotable first lieutenants who have been successful in other Army branches. Basic entry-level training into the Special Forces branch includes the Special Forces Qualification Course (which provides training on small unit tactics in unconventional warfare environments), foreign language and cultural awareness training, leadership in working with indigenous forces, mission planning and briefing skills (namely, the ability to brief concepts to Division 
and Corps staffs), and exposure to situations that require adaptive thinking in complex security environments. Upon graduation from the Qualification Course, the expectation is that a Special Forces captain can lead a highly specialized team in a myriad of operations. According to Robert G. Louis, "Special Forces captains are required to be proficient infantry commanders in addition to being experts in Special Forces operations." 70

Unlike their conventional Army counterparts-who have highly specified and controlled mission, terrain, and authority responsibilities and are "backed up," supplied, and supervised by a hierarchical succession of headquarters - the Special Forces captain is often "out there." In no other branch of the army-or any other service-are captains expected to function above the tactical level. Again, according to Louis, "In Special Forces, captains are often required to implement U.S. foreign ... the Special Forces captain is often "out there." In no other branch of the army-or any other service-are captains expected to function above the tactical level.

policy with limited diplomatic or political guidance-and failure is not an option." ${ }^{71}$ Or as General Wayne Downing often said, "in some isolated areas Special Forces captains can be the senior U.S. representative and implementer of U.S. foreign policy." 72 Indeed the most important Special Forces missions, such as unconventional warfare and strategic reconnaissance, require captain-led Special Forces Operational Detachment (SFOD) commanders to operate in failed and failing states and denied areas for extended periods of time and with little or no supervision. They will be out there.

The implications of being out there and the aforementioned assumptions and predictions for the new security environment suggest a need for educational competencies (not short-course training competencies) that would best be achieved in an academic environment at the graduate level, for several reasons.

First, junior Special Forces officers are going to be busy-very busy-and like Admiral Olson said at the Special Operations Education Conference in June 2008, they are not going to be busy in places such as the United Kingdom, Australia, and New Zealand, where English is the first language. ${ }^{73}$

Second, operations in the next several decades will necessitate the ability to adapt to increasingly diverse, remote, and antagonistic cultures and environments. ${ }^{74}$ Special Forces captains will have to be much more than 
culturally aware, which is the current requirement. They will have to achieve cultural competency, which is when the Special Forces officer demonstrates not only awareness but also cultural knowledge and sensitivity combined with an ability to gain trust and modify the behavior of allies, neutrals, or potentially divisive persons or groups to achieve a desired outcome or accomplish a mission. ${ }^{75}$ Special Forces captains will require sophisticated cross cultural communications skills. One element of the increasingly complex security environment is the exposure to a multitude of different cultures, languages, and faiths.

Cross-cultural communications will be vital for operational success in many hot spots for four reasons:

a. Effective communication among allies and coalition forces from different cultural backgrounds will ensure better teamwork and mission focus.

b. Effective communications with indigenous peoples-those the U.S. is trying to assist-will increase the likelihood for mission success.

c. Understanding the nuances of an adversary's internal and external communications (Al Qaeda's, for example) is perhaps most important. Several centuries ago, Sun Tzu said it best: If you know the enemy and know yourself, you need not fear the result of a hundred battles. If you know yourself but not the enemy, for every victory gained you will also suffer a defeat. If you know neither the enemy nor yourself, you will succumb in every battle. ${ }^{76}$

d. Cross-cultural communication can also refer to other agency cultures, including those familiar American agencies such as the CIA and Department of State as well as nongovernmental organizations (NGOs) and private volunteer organizations (PVOs). All of these agencies have different bureaucratic cultures and will be in the same battlespace as Special Forces units, often commanded by captains.

Within these settings, there are a number of communications-related knowledge competencies that are important "kit bag" skills for a Special Forces captain. Negotiations, mediation, networking, and diplomacy are among the most important. Other beneficial skills include active listening, persuasion, building rapport, understanding nonverbal communication, how to communicate through interpreters, interviewing and being interviewed, crisis communication, and writing reports. 
The third reason Special Forces officers need graduate education is the growing importance of understanding anthropology-particularly cultural, social, and political anthropology. While it is topical to address threats and conflict in religious, ethnic, and political terms-individually or collectively-the truth is that much of the conflict in the developing world is quite simply based on land-use issues. For example, in Nigeria violence between Muslims and Christians certainly has religious overtones, but pressure on resources by the northern (Muslim) nomadic cattle herders who have moved through the region have taken land and power away from the southern (Christian) indigenous peoples. It is not just the influence of fundamentalist Islam and Christianity that have polarized the two groups but also-and perhaps more significantly—the pressure on resources. ${ }^{77}$ Somalia is another example. Tribal frictions that erupted in the 1990s and remain today are based on land-use issues. Overgrazing by nomadic tribes caused the loss of more and more arable land to agricultural tribes, until the only farmable land was in Somalia's two shrinking river valleys. It was the encroachment on the river valleys by the nomadic tribes that resulted in conflict. ${ }^{78}$

Fourth, language proficiency is a cross-cultural communications enabling factor used for establishing and maintaining rapport with indigenous populations, interoperability with coalition partners, and truly understanding the intentions if not the capabilities of an adversary. This is the most difficult of the essential knowledge-based skills to learn and retain. While Special Forces language training is excellent, even those with an aptitude for learning foreign languages have difficulty attaining a professional level of expertise (3+) given the amount of time allotted to a Special Forces captain for foreign language education. Clearly, advances in Special Forces foreign language education during the MG Dave Baratto and MG Jim Parker years as commanders of the Special Warfare Center and School (SWCS) have done much to increase the SWCS's competency of Special Forces course graduates, particularly in the more difficult category languages (Arabic and Chinese, for example).${ }^{79}$ However, it remains a fact that most nonnative-speaking Special Forces soldiers-officers and noncommissioned officers-have difficulty achieving better than basic skills in a foreign language before they retire. This monograph will suggest traditional ways to improve on that, but at this point-and as a bit of aside - the author suggests three supplemental alternatives to the foreign language competency challenge-the first 
technology-related, another the best "second" alternative, and the third a reverse on the present theme.

First, there are new and emerging technologies that have instant translation capabilities. Google and other Internet browser providers have incorporated these technologies into their platforms with mixed results. Speed, depth, and accuracy are still problems. In many cases, speed is not instantaneous and often articles are not translated in total. Accuracy, particularly for the more difficult languages, is also a continuing problem. These problems will diminish as technology improves, but it will be some time before instant translation can compete with individual linguistic skills. Some emerging technology is coming out of Kuala Lumpur, developed by the person who invented the first E-ZPass technology. This technology will eventually instantly translate any language into any other language. Initially it will be in a text-to-text mode, but eventually (perhaps in less than 6 years) it will be able to do voice to voice. ${ }^{80}$ The far-ranging implications of this technology will be very beneficial for any deployed Special Forces soldier with a laptop and two sets of headphones. With this equipment, he will be able to communicate instantly with anyone who does not speak or understand English-ultimately in any language.

At a conference at the SWCS in 1992, General David Baratto asked the audience what languages the Special Forces Language School should be teaching in 2015. The answers were many and varied. Urdu, Pashto, Arabic, and Farsi were among the most frequent answers. However, seemingly less exotic languages like English, Chinese, Spanish, French, and Russian are no less important; by 2020, these languages, along with Arabic, will be either the first or second language for more than 70 percent of the world's population. ${ }^{81}$ Interestingly, the demise of the Soviet Empire might have removed Russian from consideration by most, as most of these former states' citizens prefer to study English, not Russian. However, the recent actions in Georgia suggest it might be wise to keep Russian on the list. Chinese may be questionable to some. Of course, the 1.5 billion people projected to live in China by 2020 will speak Chinese, but where else will Chinese be spoken? Interestingly, Chinese has become the most studied second language in places like Japan and South Korea. Instead of the U.S., China now attracts more exchange students from South Korea. Chinese-language courses are proliferating in Africa, as are Chinese-language television channels. ${ }^{82}$ As 
China's economic clout continues to expand around the world, it makes sense that the trends in Japan and Korea will emerge elsewhere.

Finally, it might be more cost effective to take some of the time and money Special Forces puts into foreign language training into teaching "English as a Second Language" to our allies and coalition partners that do not speak English. Admittedly, this is radical thinking, but the potential for positive diplomatic rapport building (not to mention intelligence possibilities) that could result from having a cadre of civilian teachers of English teaching English to our allies and friends in the U.S. and in their countries is immeasurable. Communication is difficult-almost impossible-if individuals cannot find a common tongue in which to converse. The traditional means of learning a foreign language will continue to be important. However, choosing the right (high density) foreign language to learn, using technology to accelerate the ability to communicate by text and voice, and realizing that it might be easier, more cost effective, and expedient to teach English to some of our allies rather than attempt to learn their languages might be other important approaches to the communication challenge.

Fifth in the list of rationales for graduate-level SOF training is that the interagency process-at the consumer level-will be an important competency for Special Forces captains. By interagency process, I am not referring to the Washington, D.C. interagency working group competencies where coordination occurs (or does not occur). This is an important competency for higher ranks such as senior O-4s, O-5s, and O-6s who will be members of interagency working groups and participants in the policy-making process. This process takes place at the country-team level of interagency competency, where captains will interface with the State Department, CIA, Drug Enforcement Agency (DEA), U.S. Agency for International Development (USAID), and perhaps other agencies, such as the Department of Agriculture and the Department of the Treasury. Not only will Special Forces team leaders have the opportunity to meet, brief, and coordinate at the embassy level, they will also meet and work with personnel from these departments and agencies in the field.

Sixth, and in the same vein as the fifth, Special Forces captains should understand the challenges and opportunities of working with NGOs. The increasingly visible role of NGOs as important players in international affairs guarantees that Special Forces units will encounter NGOs in contested and threat areas in which they will both operate. NGOs are important economic 
players that account for over 5 percent of the gross domestic product and over 4 percent of the employment in 36 of the most impoverished countries of the world. In areas where no major U.S. military operations are being conducted and no U.S. diplomatic presence exists, NGOs will probably be the best source for timely operational, logistic, economic, security, and political environment information. In many cases, NGOs will have been in the area long before any intelligence or military deployment. As such, NGO staff-particularly those of development, humanitarian assistance, and disaster relief organizations-will have a grasp of the overall situation "on the ground" in their particular area of expertise and operational area, making them excellent information (intelligence) sources and providers of ground truth..$^{83}$

Traditionally, NGOs and military organizations have had a tempestuous relationship. Though the military and NGOs have a long history of working under harsh conditions and even in the same remote and dangerous locations, the two groups have traditionally tried to avoid collaborative efforts, both believing that their work was essentially incompatible. Given the likelihood that the military will be working with NGOs more frequently and far into the future, its operational-level leadership would benefit by learning to better understand how broadly its organization differs from NGOs and take steps needed to bridge the cultural gap that separates them in order to achieve common goals. ${ }^{84}$

\section{Summary of Education Requirements}

The preceding paragraphs do not cover all of the knowledge-based education a Special Forces captain should posses before contemplating an assignment out there, and others are welcome to add to the list. However, the competencies outlined will not just be useful to SOF officers-they could be missionand life-essential. At the end of the day, a Special Forces captain is going to be most successful if he can resolve conflict before it gets to a kinetic level. To succeed, he will have to be able to do more than just influence people of different cultures, both indigenous and bureaucratic. Often he will need to get them to change their behavior-and even more difficult, he will have to get them to do what they do not necessarily want to do. Negotiation skills, cross-cultural communication expertise, language proficiency, and cultural and anthropological aptitude are all competencies that will enable a Special 
Forces captain to lead, influence, and perhaps even survive where there is little or no local or outside support.

Why does this paper advocate a graduate program when others might promote a less vigorous and time-consuming alternative? The answer is capacity-based. Clearly, you can train an officer to be able to interact, negotiate, and work with a local group such as the Bedouin in a quick, compressed, PowerPoint training environment-the "staff of life" at the SWCS. However, will that training prepare him to work with the Berber, Chawis, Rifains, or seven other nomadic tribes in North Africa? ${ }^{85}$ More importantly, will it give him the capacity to work with the 403 other tribes in Africa? Probably not. And in fact, trying to use his Bedouin training to influence other tribes could be counterproductive or worse. Graduate education in cultural anthropology, cross-cultural communication, and negotiations would give him the knowledge to avoid cultural faux pas, ask the right questions, and interact effectively in many tribal environments. It will also give him the ability and flexibility to adapt quickly to different ethnic and cultural environments. Training can prepare a trainee for a specific situation and/or event. Graduate study is more focused on a specific area of interest and on acquiring specialized skills to practice at a professional level. This does not merely entail taking a number of courses. It requires active participation in the continuous discovery of new knowledge. Training is event- or skillfocused; education is for a career.

\section{Analysis of Select Graduate Programs}

The Joint Special Operations University president, Dr. Brian Maher, articulated the requirement for "unique and tailored masters programs" in his presentation "The Way Forward" in the spring of 2008. He identified future programs being developed at the University of North Carolina, James Madison University, and the Combined Arms Center at Fort Leavenworth in conjunction with the University of Kansas or Kansas State University. ${ }^{86}$ An existing option is the Special Operations/Irregular Warfare program at the Naval Postgraduate School. Other possible options could be distancelearning programs at The Fletcher School of Law and Diplomacy, Tufts University and Norwich University and a proposed combined distance learning and residence program at the University of Montana. Time-and-space constraints limit the number of graduate programs reviewed for this project, 
and assuredly, other possibilities than the half dozen that are reviewed here exist. However, this is a good sampling of proposed and existing resident and distance-learning programs. ${ }^{87}$

The proposed University of North Carolina-Chapel Hill "Peace, War, and Defense" program mentioned in Dr. Maher's briefing is presently an undergraduate, not graduate, program. In its undergraduate form, the Peace, War, and Defense program has a menu of more than 70 courses that include historical, regional, international relations, public policy, security studies, and terrorism titles. There is even a course entitled "War in Shakespeare's Plays." 88 The obvious shortcoming of this program is that it is not yet a graduate curriculum. Also, while the course offerings are robust, only one course - "Anthropology of War and Peace"-fits the criteria outlined in this monograph. Also, most of the course offerings are more theoretical than operational or policy-oriented. ${ }^{89}$

The James Madison University graduate program focuses on development and will prepare Civil Affairs officers for senior command and staff positions. The precursor to the graduate program was a 6-week program for Civil Affairs O-4s and O-5s first taught in September 2008. The proposed curriculum for the graduate course includes research methods, ethics and leadership, public management issues, international relations, public information and communication, communication in conflict situations (including mediation and conflict resolution and cross-cultural communication), and strategic planning. The program concludes with a "capstone event" that will challenge students to use their cumulative course knowledge to develop a country report, campaign plan, and business plan. ${ }^{90}$

The proposed Combined Arms Center graduate program in "Interagency Studies" for SOF students attending Intermediate Level Education (ILE) at Fort Leavenworth is in the early implementation phase. As its title implies, the intent of the Interagency Studies Program is to prepare special operations officers and others to understand and conceivably work in the interagency environment. The course will address interagency organizations and responsibilities, including embassy country teams, Congress and the legislative process, staffs and congressional delegations, the National Security Council, and the interagency process. Other core topics will include interagency organizations and organizational cultures, organizational behavior, negotiation theory and execution, legal considerations, and international relations. The program also includes a 3-month internship where a student 
applies "theory to practice" in a SOF-related interagency assignment. ${ }^{91}$ This program would be offered in conjunction with the University of Kansas or Kansas State University.

The current "flagship" special operations graduate program is the "Special Operations/Irregular Warfare" curriculum at the Naval Postgraduate School in Monterey, California. The program has been in existence for several years and has an annual throughput of 55 SOF students from all the services in the grade of O-4 or O-5 (with the largest majority being Army Special Forces officers). The Special Operations/Irregular Warfare curriculum primarily focuses on international relations and security studies and is an excellent platform for preparing field grade officers for future command and higherlevel staff positions in the SOF community. The curriculum is designed to provide a course of study that focuses on the conflict spectrum "below general conventional war." 92 Graduates of the program possess a detailed understanding of the role of SOF in U.S. foreign and defense policy as well as knowledge of the factors involved in planning for irregular warfare. ${ }^{93}$

Several distance-learning programs also offer master's degrees in disciplines useful to Special Forces officers. This paper will review three. The premier program is the Global Master of Arts Program (GMAP) at The Fletcher School, Tufts University. GMAP is a unique 1-year international studies degree program designed for mid-to-senior-level professionals, combining flexible Internet-mediated study with three 2-week residency sessions. According to GMAP's promotional material, the program "delivers a rigorous and dynamic education that is unique in form and content, by integrating the strength of The Fletcher School's cross-disciplinary curriculum with today's innovative technologies, and having a culture focused on teamwork and close collaboration among participants, faculty, and staff." ${ }^{94}$ GMAP is a combination of distance and residence learning. The residencies provide an intensive classroom experience and personal contact that form the foundation for student and student-professor interaction. The initial residency is held on The Fletcher School campus in Medford, Massachusetts and provides the first opportunity for students to meet each other and the GMAP faculty and administration. The mid-year residency is held outside the U.S. in places such as Costa Rica, Spain, Greece, Mexico, Singapore, the Netherlands, or Argentina. Finally, a closing residency is held at The Fletcher School at the end of the program to complete the theses and finalize all coursework before graduation. GMAP courses include international 
politics, international finance, international negotiation, international trade, transnational social issues (human security and environmental issues), foreign policy, and international organizations.

Norwich University's Master of Arts in Diplomacy offers three concentrations: a) International Terrorism, b) International Conflict Management, and c) International Commerce. All offer strategic-level competencies useful to Special Forces officers. However, the International Terrorism and the International Conflict Management concentrations offer seminars that are particularly pertinent to Special Forces officers' needs. The Norwich program's core curriculum provides a systematic overview of the historical and current theories for a broad range of core topics, including international law, humanitarian intervention, globalization, and international economics. ${ }^{95}$ The International Terrorism concentration focuses on two major aspects of terrorism-state sponsored and nonstate sponsored-and also explores the international community's response to the global terrorism threat. ${ }^{96}$ The International Conflict Management concentration focuses on conflict avoidance, conflict management, and mitigation in an increasingly conflictoriented world and is designed for civilian and military professionals who must apply diplomacy and conflict resolution skills to reduce the opportunities for conflict. ${ }^{97}$

The Norwich program (all three concentrations) is a 36-credit degree comprised of six 6-credit seminars. There are four start dates per year: March, June, September, or December. Each seminar is approximately 11 weeks in length. The core curriculum is composed of three seminars focusing on the Global System, while the remaining three seminars allow individual selection of one of the three concentration areas. The three core seminars and the three seminars from a concentration area must be taken in the order they are presented, as they are strategically sequenced to build context for future seminars and to build on issues from past seminars. The Norwich program can be completed in 18 months and costs approximately $\$ 24,000$. With the exception of a final 1-week residence phase prior to graduation, the Norwich program is held in a small-group, distance-learning format.

There are few downsides to the Norwich University program. Comparatively, it is cost competitive and can be completed online. As long as a student has a computer and Internet access, he or she can complete the program. One shortfall is the lack of a "cultural and political anthropology" course. However, the cross-cultural communications and negotiations 
course offered may suffice. Another limitation might be the lack of regional courses. However, students are allowed two "independent studies" which could be regionally focused.

The University of Montana's “Interdisciplinary Master's Degree” distance-learning program is in the planning stages. Interestingly, it is a novel 5 -year program that would provide practitioner-level anthropology, communications, negotiations, interagency (country team), and regional courses at the beginning of the program and the more theoretical international relations theory, interagency process (Washington), and security studies courses toward the middle and the end of the program. Because Montana is such a large and sparsely populated state, the University of Montana's Continuing Education Department has been offering external degree programs for a number of years, primarily at the doctoral and master's degree levels. Originally, the school offered programs face-to-face; however, in the last decade significant growth has occurred in mediated or blended methods of learning that include traditional classroom, video conferencing, and online instruction, with an emphasis on the latter. These degree programs have been designed to meet the needs of students who cannot come to campus for prolonged time periods.

According to the University of Montana concept, the proposed Interdisciplinary Master's Degree distance-learning program would be "cost effective, available globally, and specially tailored for military, diplomatic, development, and NGO personnel." ${ }^{\text {98 }}$ The 36-credit hour degree would combine courses focusing on leadership and analysis, international relations, microdevelopment economics, social and cultural anthropology, national security, cross-cultural communications, the interagency process, terrorism, negotiations, and regional courses. The school will award 6 credit hours for previously attained foreign language proficiency, and a limited number of credits can be transferred into the program. An on-site resident phase at the University of Montana will be available but not mandatory. Anticipated per-student costs will be in the $\$ 15,000$-to- $\$ 20,000$ range, depending on the number of students in the program.

\section{Graduate Program Summary}

All of the programs researched for this paper have merit and all include courses relevant to special operations and to various degrees, Special Forces officers. While it is too soon to comprehensively evaluate the resident courses 
in the design phase mentioned in the Maher briefing-including the University of North Carolina-Chapel Hill "Peace, War, and Defense" program, James Madison University's "Civil Affairs" program, and the Combined Arms Center "Interagency Studies" program-it is fairly safe to say that all three cater to "niche" rather than comprehensive knowledge competencies. The titles of the James Madison and Combined Arms Center programs clarify their intent and audience: Civil Affairs and interagency operations. The Chapel Hill program, at least if the undergraduate program design is followed, will emphasize historical and theoretical constructs. While all of these programs as envisioned are good, none provides the comprehensive course-set required by Special Forces officers, at least in this author's view. Furthermore, residence programs will continue to prove difficult for Special Forces officers given the assumptions of this paper that they will be deployed as much as they are now, and possibly more.

Clearly, the Naval Postgraduate School "Special Operations/Irregular Warfare" program is the best option for the major/lieutenant commanderlevel officer on track for higher Special Operations Command and staff positions. The program, under the tutelage of Dr. Gordon McCormick, has become an outstanding education experience. Course offerings are relevant, topical, and current. Furthermore, Dr. McCormick has attracted a gifted set of special operations savvy Ph.D. individuals such as Hy Rothstein, Gunner Sepp, and John Arguilla, among others. The limitations of the program are the throughput (50 students a year from all services) and the grade at which an officer matriculates (major and lieutenant commander).

The limitations of the Fletcher School's GMAP course for Special Forces officers include cost, time, curriculum, and prerequisites. First, GMAP carries a hefty price tag- $\$ 50,000$ for the full program, which is more than some comparable residence programs at elite universities. Second, the student generally must complete the course with his/her cohort in 1 year (there are some exceptions). Third, the GMAP curriculum is strategic and intended for students at the major or lieutenant colonel stage of their careers and headed for staff positions in Washington. Also, the curriculum is lacking in the anthropology, intercultural communications, and regional studies courses required by "operators." Finally, a prerequisite calling for a minimum of 8 years professional experience precludes most Special Forces captains from matriculating. ${ }^{99}$ The program also seems to have limited appeal for Army 
officers-only 12 have gone through the program in 5 years, and none of those have been SOF officers.

The intent of this monograph is not to make recommendations about specific programs, but to suggest types of programs that have the most "cache" for the graduate requirements suggested in this work. From pedagogical, course selection, and flexibility perspectives, the existing Norwich University model and the planned University of Montana model seem to offer promise. The Norwich program can be completed in 18 months, but can also be extended over a longer period of time as long as the core and specialization modules are completed in a designated sequence. The course selection menu, particularly in the International Conflict Management concentration, is close to what this paper recommends. The independentstudy options would most likely allow students the opportunity to "make up the difference" under directed study. The cost of the Norwich programapproximately $\$ 24,000$-is a good value in today's tuition market. By offering four course start times a year (March, June, September, or December) and an inclusive distance-learning package (the only residence phase is the last week before graduation), this program offers maximum flexibility to students who are deployed or deploying.

The proposed University of Montana program has many of the same characteristics as the Norwich program (36 credits, inclusive distance learning, and flexible start times) but would offer even more flexibility. The "Interdisciplinary Master's Degree" can be taken over a 5-year period and offers "practical knowledge" vice theoretical courses in the first 2 years of the program. During the last 3 years of the program, more theoretical and strategic courses will be offered. Six hours (credits) of language training qualify as transferable credit into the program. The cost of the Norwich program- $\$ 20,000$ to $\$ 25,000$ - is competitive with other programs. And, as planned, the program would have an optional, summer resident phase for certain courses at the University of Montana. The downside at the University of Montana is that there is not a strong Africa regional program at the university; it is a limitation given Africa's increased importance from a security perspective. 


\section{Special Forces Officers Graduate Opportunities}

Compared with Army-at-large graduate school figures, Special Forces officers do not attend in the same numbers as their non-Special Forces counterparts. See Table $1 .^{100}$ At the colonel level only 6 percent of non-Special Forces do not have master's degrees, whereas 15 percent of their Special Forces counterparts at that grade do not have an advanced degree. The most striking disadvantage is in the 0-3 and 0-4 grades. Only 3 percent of Special Forces captains have master's degrees, while 12 percent of non-Special Forces Army captains have them. Of non-Special Forces Army majors, 44 percent have master's degrees, while only 28 percent of Special Forces majors have an advanced degree. Of non-Special Forces lieutenant colonels, 80 percent have higher degrees, while only 69 percent of Special Forces officers in that grade have higher degrees.

Table 1a. Non-SF and SF Graduate Degrees

Counts (Percents) by Years of Service

Population=All ACC Non-SF Officers

\begin{tabular}{c|c|c|c|c|c}
\hline $\begin{array}{r}\text { Degree } \\
\text { Years Type } \\
\text { of Service }\end{array}$ & Total & $\begin{array}{c}\text { Fully } \\
\text { Funded }\end{array}$ & $\begin{array}{c}\text { Military } \\
\text { Graduate } \\
\text { Degree }\end{array}$ & $\begin{array}{c}\text { Not } \\
\text { Fully } \\
\text { Funded }\end{array}$ & $\begin{array}{c}\text { No } \\
\text { Graduate } \\
\text { Degree }\end{array}$ \\
\hline $\mathbf{0 - 4}$ & 22,668 & $292(1 \%)$ & $4(0 \%)$ & $1,095(5 \%)$ & $21,277(94 \%)$ \\
\hline $\mathbf{5 - 9}$ & 11,435 & $145(1 \%)$ & $11(0 \%)$ & $1,931(17 \%)$ & $9,348(82 \%)$ \\
\hline $\mathbf{1 0 - 1 4}$ & 7,731 & $1,153(15 \%)$ & $293(4 \%)$ & $2,019(26 \%)$ & $4,266(55 \%)$ \\
\hline $\mathbf{1 5 - 1 9}$ & 7,391 & $1,767(24 \%)$ & $590(8 \%)$ & $3,223(44 \%)$ & $1,811(25 \%)$ \\
\hline $\mathbf{2 0 +}$ & 5,466 & $1,416(26 \%)$ & $700(13 \%)$ & $2,578(47 \%)$ & $772(14 \%)$ \\
\hline N/A & 217 & 6 & 0 & 25 & 186 \\
\hline Total & 54,908 & $4,779(9 \%)$ & $1,598(3 \%)$ & $10,871(20 \%)$ & $37,660(69 \%)$ \\
\hline
\end{tabular}

Population=SF Officers

\begin{tabular}{c|r|r|r|r|r}
$\begin{array}{c}\text { Years } \\
\text { of Service }\end{array}$ & \multicolumn{1}{|c|}{$\begin{array}{c}\text { Degree } \\
\text { Type }\end{array}$} & $\begin{array}{c}\text { Fully } \\
\text { Total }\end{array}$ & $\begin{array}{c}\text { Military } \\
\text { Graduate } \\
\text { Degree }\end{array}$ & $\begin{array}{c}\text { Not } \\
\text { Fully } \\
\text { Funded }\end{array}$ & $\begin{array}{c}\text { No } \\
\text { Graduate } \\
\text { Degree }\end{array}$ \\
\hline $\mathbf{0 - 4}$ & 473 & $0(0 \%)$ & $0(0 \%)$ & $14(3 \%)$ & $459(97 \%)$ \\
\hline $\mathbf{5 - 9}$ & 493 & $5(1 \%)$ & $1(0 \%)$ & $21(4 \%)$ & $466(95 \%)$ \\
\hline $\mathbf{1 0 - 1 4}$ & 320 & $18(6 \%)$ & $42(13 \%)$ & $37(12 \%)$ & $223(70 \%)$ \\
\hline $\mathbf{1 5 - 1 9}$ & 262 & $25(10 \%)$ & $76(29 \%)$ & $75(29 \%)$ & $86(33 \%)$ \\
\hline $\mathbf{2 0 +}$ & 183 & $18(10 \%)$ & $50(27 \%)$ & $72(39 \%)$ & $43(23 \%)$ \\
\hline N/A & 6 & 0 & 0 & 1 & 5 \\
\hline Total & 1,737 & $66(4 \%)$ & $169(10 \%)$ & $220(13 \%)$ & $1,282(74 \%)$ \\
\hline
\end{tabular}


Table 1b. Non-SF and SF Graduate Degrees

Counts (Percents) by Grade

Population=All ACC Non-SF Officers

\begin{tabular}{c|r|r|r|r|r}
$\begin{array}{c}\text { Pay } \begin{array}{c}\text { Degree } \\
\text { Tyade }\end{array} \\
\text { Type }\end{array}$ & Total & $\begin{array}{c}\text { Fully } \\
\text { Funded }\end{array}$ & $\begin{array}{c}\text { Military } \\
\text { Graduate } \\
\text { Degree }\end{array}$ & $\begin{array}{c}\text { Not } \\
\text { Fully } \\
\text { Funded }\end{array}$ & $\begin{array}{c}\text { No } \\
\text { Graduate } \\
\text { Degree }\end{array}$ \\
\hline $\mathbf{0 1}$ & 9,167 & $241(3 \%)$ & $1(0 \%)$ & $218(2 \%)$ & $8,707(95 \%)$ \\
\hline $\mathbf{0 2}$ & 5,738 & $8(0 \%)$ & $0(0 \%)$ & $248(4 \%)$ & $5,482(96 \%)$ \\
\hline $\mathbf{0 3}$ & 17,266 & $112(1 \%)$ & $3(0 \%)$ & $2,005(12 \%)$ & $15,146(88 \%)$ \\
\hline $\mathbf{0 4}$ & 11,530 & $1,525(13 \%)$ & $397(3 \%)$ & $3,150(27 \%)$ & $6,458(56 \%)$ \\
\hline $\mathbf{0 5}$ & 8,241 & $2,067(25 \%)$ & $654(8 \%)$ & $3,840(47 \%)$ & $1,680(20 \%)$ \\
\hline $\mathbf{0 6}$ & 2,966 & $826(28 \%)$ & $543(18 \%)$ & $1,410(48 \%)$ & $187(6 \%)$ \\
\hline Total & 54,908 & $4,779(9 \%)$ & $1,598(3 \%)$ & $10,871(20 \%)$ & $37,660(69 \%)$ \\
\hline
\end{tabular}

Population=SF Officers

\begin{tabular}{c|r|r|r|r|r}
\multicolumn{1}{c|}{$\begin{array}{c}\text { Degree } \\
\text { Trade }\end{array}$} & Type & $\begin{array}{c}\text { Fully } \\
\text { Funded }\end{array}$ & $\begin{array}{c}\text { Military } \\
\text { Graduate } \\
\text { Degree }\end{array}$ & $\begin{array}{c}\text { Not } \\
\text { Fully } \\
\text { Funded }\end{array}$ & $\begin{array}{c}\text { No } \\
\text { Graduate } \\
\text { Degree }\end{array}$ \\
\hline $\mathbf{0 1}$ & 0 & 0 & 0 & 0 & 0 \\
\hline $\mathbf{0 2}$ & 3 & $0(0 \%)$ & $0(0 \%)$ & $0(0 \%)$ & $3(100 \%)$ \\
\hline $\mathbf{0 3}$ & 865 & $1(0 \%)$ & $0(0 \%)$ & $30(3 \%)$ & $834(96 \%)$ \\
\hline $\mathbf{0 4}$ & 466 & $23(5 \%)$ & $56(12 \%)$ & $52(11 \%)$ & $335(72 \%)$ \\
\hline $\mathbf{0 5}$ & 305 & $33(11 \%)$ & $76(25 \%)$ & $101(33 \%)$ & $95(31 \%)$ \\
\hline $\mathbf{0 6}$ & 98 & $9(9 \%)$ & $37(38 \%)$ & $37(38 \%)$ & $15(15 \%)$ \\
\hline Total & 1,737 & $66(4 \%)$ & $169(10 \%)$ & $220(13 \%)$ & $1,282(74 \%)$ \\
\hline
\end{tabular}

Notes:

1. Data as of 30 September 2007

2. Fully funded $=$ Graduate degree awarded as part of Advanced Civil Schooling (ACS) program

3. Military graduate degree $=$ Obtained a graduate degree as part of attendance at a military course such as ILE or AWC

4. Not fully funded = Obtained graduate degree under tuition assistance or other non-ACS program

Funding is also an equity issue. Non-Special Forces officers have more than twice the number of fully funded graduate opportunities than their Special Forces counterparts ( 9 percent compared to 4 percent). Special Forces officers tend to earn "military graduate degrees," presumably while attending the ILE or the War College, at more than three times the percentage as non-Special Forces officers (10 percent vs. 3 percent). ${ }^{101}$ Interestingly, nonSpecial Forces officers were able to self-fund graduate degree opportunities at a higher percentage than their Special Forces counterparts (20 percent to 13 percent), probably because they are "stabilized" at a given post and 
can continue to work towards degrees at on-post, off-site degree programs at Army Education Centers. Special Forces officers have difficulty completing degrees in these programs not just because of war-time deployment schedules but also because of demanding TDY deployments while back at home station. ${ }^{102}$

Based on these statistics and analysis, one should not draw any conclusions of nefarious Army discrimination between Special Forces and nonSpecial Forces officers graduate degree opportunities. It is most likely that non-Special Forces officers have more discretionary time to participate in a host of funded, nonfunded, and partially funded programs because of fewer rotations (for many but not all units) and less demanding TDY schedules. ${ }^{103}$ However, the statistics point out with some clarity that Special Forces officers do not have the same graduate opportunities, when it could be argued that they should have more, if not universal, graduate study opportunities.

So, what to do? A Special Forces officer's "development model" is already crowded (see Figure 1) and there is little, if any time for resident graduate schooling except in special circumstances (i.e., West Point, ROTC assignments) until he is a very senior captain through colonel-level officer. This

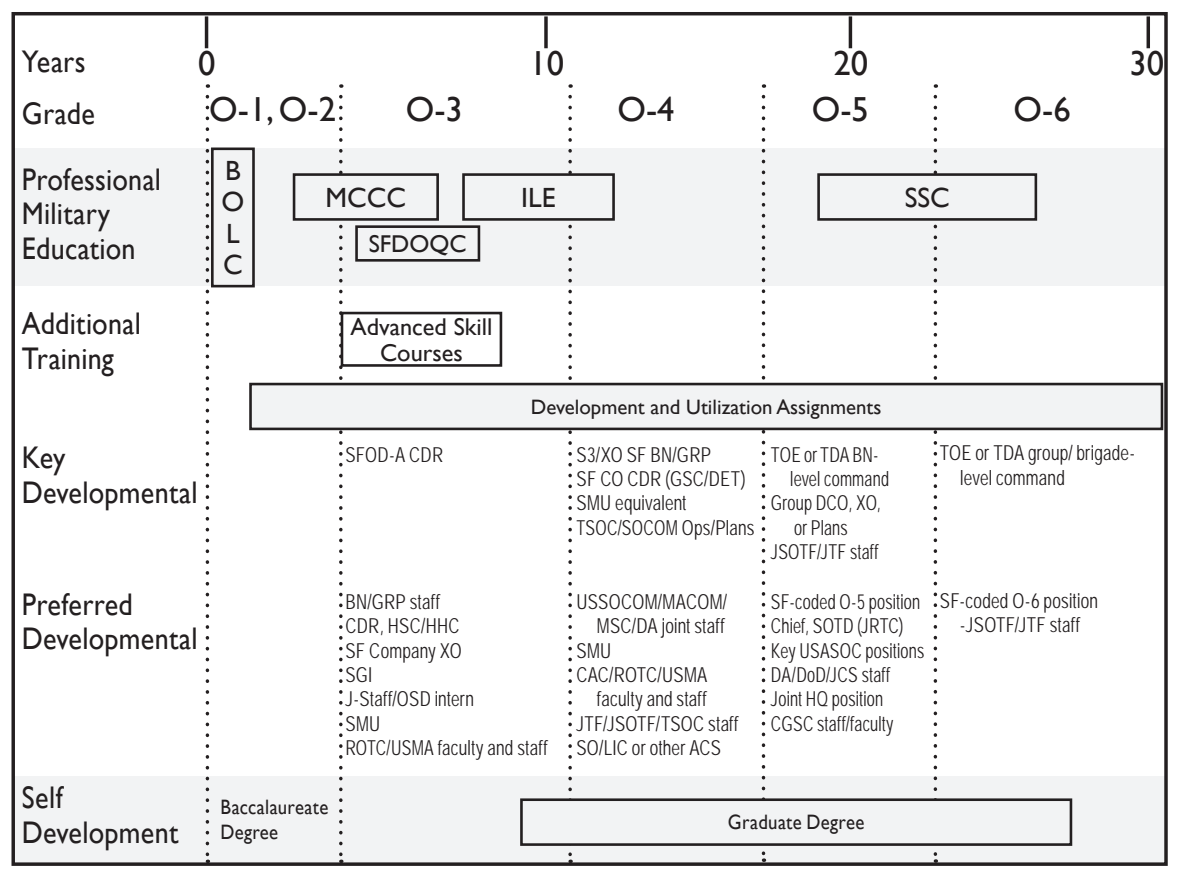

Figure 1. Special Forces Officer "Development Model" 104 
monograph recommends that graduate skills necessary for captain-level operational competencies be front-loaded early in a Special Forces captain's career and that strategic and theoretical courses required for later command and staff assignments be taken during the "early major" years. Other than preparing the officer for a post-retirement career, a graduate degree earned at the grade of lieutenant colonel or colonel has limited Special Forces value.

For the model described in this monograph to work, two nontraditional approaches must be employed. First, the time necessary to complete the degree must be extended from 2 to 5 years. Second, greater reliance on distance learning (Internet/computer-based) over residence learning must be emphasized. Additionally, hosting universities should consider course credit for language training and perhaps other knowledge-based courses at the Special Warfare Center and School (the follow-on to the "Regional Studies Course" comes to mind) to be transferable.

Clearly, these suggestions should be reviewed with care and critiqued by educators and practitioners. Rather than limiting courses to the fields described above, a range of other topics-such as international relations, international economics, microeconomics, geography, development, and environmental policy-should be considered as possible elective or even core courses. Experts will differ on the finer points of the programs, and their opinions should be a key factor in developing options and alternatives. However, one topic - culture-is not negotiable. The case of the U.S. intelligence community illustrates how a lack of cultural knowledge can be a weakness. Currently, U.S. intelligence processes focus on political, economic, security, and leadership analysis. Analysts are not trained with specific skills in researching cultural data, nor are they assigned the task of defining the parameters of a foreign society's rationality (strategic culture). While many in the intelligence community recognize the need to know information about a foreign culture, they seek it out on their own. The practice is not emphasized, institutionalized, or resourced. As a result-at least in the view of the author and of others-the intelligence community is left open to committing serious policy mistakes. According to one observer, "Understanding culture is essential in forecasting events, building good will on the ground, engaging in successful negotiations, and the entire host of other occupations within our foreign policy structure." 105 Those who are culturally ignorant do not win wars for hearts and minds. ${ }^{106}$ 


\section{Concluding Remarks}

The assumptions and future international security environment portions of this work were written before the Army's Stability Operations Field Manual and the Marine Corps' Operational Culture for the Warfighter: Principles and Applications reference textbook were published. Upon review of both, the author is inclined to believe that his original assumptions and analysis of the future international security environment are on the mark. Some might disagree with the degree of attention paid to regional powers such as Russia, India, and China in this work. However, my experiences in Georgia, Central Asia, and Africa in recent years lead me to believe that U.S. Special Forces will increasingly confront operators, surrogates, and possibly forces from these emerging powers while doing this nation's business in the developing world.

The knowledge-based educational competencies suggested here are certainly subject to debate. The suggestions are based on mostly anecdotal data gleaned from former students returned from multiple tours in Iraq, Afghanistan, the Philippines, and other hot spots and on the author's personal, much less demanding but equally lengthy operational experience in the developing world, both in and out of uniform. Seven missions in Africa in the past year have certainly influenced the opinions rendered here.

While this analysis is intended to be a starting point for discussion, all suggestions are negotiable save for the culture-based courses. Again, it is impossible to learn the vagaries of every disparate culture a Special Forces officer will face in a career. However, it is possible to learn the macro fundamentals of culture so that a Special Forces operator knows which questions to ask and what pitfalls to avoid before engaging those from a particular culture. Just as in baseball, where a player has to first know the fundamentals before advancing to more competitive leagues, knowing the fundamentals of anthropology, communications, and negotiations will allow the Special Forces operator to quickly learn how to perform in any cultural environment. Presently, Special Forces soldiers often learn their "culture stuff" after some "crucible experience." 107 We can do better than that.

The survey of graduate programs in this study was limited by time and space. Most certainly, other programs are worthy of review, and interested parties are encouraged to do so. However, the programs cited here are good representative samples of the types of programs both currently available and 
in the planning stages. The author is more familiar with the Fletcher School and proposed University of Montana programs because of past and present associations with both institutions. Those associations and avoidance of any conflict-of-interest issues are the reason that no particular university program is recommended in this work. Instead, this survey recommended a graduate school formula-distance-learning intensive; an emphasis on operational skills first, strategic skills last; and a completion period of 5 years instead of the traditional 2.

The graduate degree opportunity gap - both funded and nonfundedbetween non-Special Forces and Special Forces officers is real, and needs to be addressed at the command level. The gap is not nefarious, and discrimination is not the issue. Available time, deployments, other operational requirements, and the lack of nontraditional alternatives are the reasons for the gap. Hopefully some of the suggestions and alternatives highlighted in this work will help to reduce or possibly reverse the gap in the Special Forces favor. $\uparrow$ 


\section{Endnotes}

1. Andrew Winston, "Will Your Company Predict the Future Like GM or Like Toyota?," Harvard Business Publishing 16 July 2008. Available at http://blogs. harvardbusiness.org/leadinggreen/2008/07/roadkill-how-detroit-missed-th.html (accessed May 2009).

2. Among the most recent-compiled by the author and Major Paul Oh of the U.S. Military Academy-follow:

a. Ensuring Security in an Unpredictable World: Project on National Security Reform Preliminary Findings, Project on National Security Reform, Center for the Study of the Presidency, July 2008

b. Joint Operating Environment (JOE): Trends and Challenges for the Future Joint Force Through 2030, United States Joint Forces Command, December 2007

c. Forging a World of Liberty Under Law: U.S. National Security in the 21st Century, Princeton Project on National Security (PPNS), Woodrow Wilson School of Public and International Affairs, 2006

d. The New Global Puzzle: What World for the EU in 2005?, European Union Institute for Security Studies, 2006

e. Global Strategic Trends Programme 2007-2036, United Kingdom Ministry of Defense Development, Concepts, and Doctrine Centre (DCDC), 2007

f. Howard's Formula for Conflict- “Strategic Futures," presentations to the 7 th Special Forces Group and the Kofi Annan Peacekeeping Center, Accra, Ghana, 2008.

3. Paul Oh, "Future Strategic Environment in an Era of Persistent Conflict," draft article for discussion at the U.S. Military Academy Senior Conference, June 2008. Presented in West Point, New York, 5-7 June 2008.

4. Ibid., p. 1.

5. Ibid., p. 2. See also National Intelligence Council (NIC), Mapping the Global World (Government Printing Office, 2004), p. 10.

6. Ibid., p. 2-3. See also European Union Institute of Security Studies (EUISS), The Global Puzzle.

7. Ibid., p. 3.

8. Ibid. See also DCDC, The DCDC Global Strategic Trends Programme, p. 3.

9. Global Issues, Poverty Facts and Statistics, March 2004. Available at www.globalissues.org/TradeRelated/Facts.asp (accessed May 2009).

10. The author has made six trips to Africa in 8 months, and this is a standard figure used by all relief, humanitarian, and development agencies in the region. See also Oh, p. 3.

11. Philippe Legrain, "Cultural Globalization Is Not Americanization," The Chronicle of Higher Education, 9 May 2003. Available at: http://chronicle.com/free/v49/ i35/35b00701.htm (accessed May 2009). 
12. "Globalization and the Root Causes of Terrorism," transcript of live online chat with William Christison, former CIA director, Office of Regional and Political Analysis. The Washington Post Online, 10 April 2001. Available at: http://discuss. washingtonpost.com/wp-srv/zforum/02/nation_christison0410.htm (accessed May 2009).

13. Oh, p. 3.

14. Ibid., p. 4.

15. Ibid.

16. EUISS, p. 15.

17. Oh, p. 4. See also United States Joint Forces Command, JOE, p. 10.

18. Oh, p. 4.

19. Ibid. See also "Young, alive, but not very heaven," The Economist, 2 February 2008, p. 54.

20. Ibid. See also United States Joint Forces Command JOE, p. 10.

21. Kate Johnston, “Climate Change: a Cause of Conflict?," Global Politics Magazine, January 2008. Available at www.globalpolicy.org/security/natres/water/2008/012 008climateconflict.htm (accessed May 2009).

22. Ibid.

23. Dr. Zachariha Ousman lecture to Civil-Military Operations Course in Accra, Ghana, 25-29 July 2008.

24. Julian Borger, "Darfur Conflict Heralds Era of Wars Triggered by Climate Change, UN Report Warns," The Guardian, 23 June 2007. Available at www.guardian. co.uk/environment/2007/jun/23/sudan.climatechange (accessed May 2009).

25. Conversations with Michael Sheehan, Special Assistant to the Special Representative for the Secretary General at the UN, January 1994.

26. Oh, p. 6.

27. EUISS, p. 54.

28. PPNS, Forging a World of Liberty Under Law, p. 51.

29. Oh, p. 7.

30. Sarina Locke, "Water, More Important than Oil," NSW Country Hour Summary, 21 August 2003. Available at www.abc.net.au/rural/nsw/stories/s929204.htm (accessed May 2009).

31. Ibid.

32. David Hopkins, "Depletion of Water Resources More Serious than Oil Reserves," Environmental Data Interactive Exchange, July 2005. Available at www.edie.net/ news/news_story.asp?id=9562\&channel=0 (accessed May 2009).

33. Ibid.

34. Ibid.

35. Ibid.

36. Oh, p. 7.

37. Ibid. 
38. Russell D. Howard, "The New Terrorism," in Terrorism and Counterterrorism: Understanding the New Security Environment, Russell D. Howard, Reid L. Sawyer, and Natasha E. Bajema, eds., Third Edition, McGraw-Hill, 2008, p. 118.

39. Russell D. Howard and Colleen Traughber, "The 'New Silk Road' of Terrorism and Organized Crime," in Armed Groups: Studies in National Security, Counterterrorism, and Counterinsurgency, Jeffrey H. Norwitz, ed. (U.S. Naval War College, 2008), p. 371.

40. Alison Jamieson, "Transnational Organized Crime: A European Perspective," Studies in Conflict \& Terrorism No. 24 (2001): 377-387, p. 380.

41. Ibid., 378.

42. Troy S. Thomas and Stephen D. Kiser, "Lords of the Silk Route: Violent Nonstate Actors in Central Asia," INSS Occasional Paper 43 (2002), p. viii.

43. John Arquilla, David Ronfeldt, and Michele Zanini, "Networks, Netwar, and Information-Age Terrorism," in Terrorism and Counterterrorism, pp. 134-157.

44. Ibid.

45. "Russia: Industry," Encyclopedia of the Nations, 2008. Available at www.nationsencyclopedia.com/economies/Europe/Russia-INDUSTRY.html (accessed May 2009).

46. Ibid.

47. Russia's per capita GDP ranks 75th in the world, behind Croatia; see "Rank Order-GDP-Per Capita (PPP)," CIA World Fact Book, updated 6 November 2008; available at www.cia.gov/library/publications/the-world-factbook/ rankorder/2004rank.html (accessed May 2009). Russia's total GDP is 6th in the world, behind Germany; see "Gross Domestic Product 2007, PPP," World Development Indicators Database, The World Bank, 17 October 2008; available at http://siteresources.worldbank.org/DATASTATISTICS/Resources/GDP_PPP. pdf (accessed May 2009).

48. "India is Now More Populous than China," News of Future Web site. Available at www.newsoffuture.com/india_is_now_more_populous_than_china_future_ population.html (accessed May 2009).

49. Sanjoy Hazarika, "Powerful but Ill-Defined: Rising India Middle Class," International Herald Tribune, 30 July 1996. Available at: www.iht.com/articles/1996/07/30/ india.t_1.php (accessed May 2009).

50. Rich Thomas, "India's Military Modernization Surges Ahead," Associated Content, 13 December 2007. Available at www.associatedcontent.com/article/482271/ indias_military_modernization_surges.html (accessed May 2009).

51. Cait Murphy, "India the Superpower? Think Again,” Fortune, 9 February 2007. Available at http://money.cnn.com/2007/02/08/news/international/pluggedin_ murphy_india.fortune/index.htm (accessed May 2009).

52. “53\% - China the Superpower?," Pew Research Center: The Databank, 8 August 2008. Available at http://pewresearch.org/databank/dailynumber/?NumberID=575 (accessed May 2009). 
53. Russell D. Howard, “The Chinese People's Liberation Army: 'Short Arms and Slow Legs,"” INSS Occasional Paper 28, September 1999, p. 38.

54. Ellen L. Frost, James J. Przystup, and Phillip C. Saunders, "China's Rising Influence in Asia: Implications for U.S. Policy," Strategic Forum, No. 231, Institute for National Strategic Studies, April 2008, p. 4.

55. Ibid.

56. Ibid.

57. Fred Kaplan, “The China Syndrome: Why the Pentagon Overstates Beijing's Military Capabilities," Slate.com, 26 May 2006. Available at www.slate.com/id/2141966 (accessed May 2009).

58. “China's Defense Budget to Rise 17.8\% in 2007," The China Daily, 4 March 2007, p. 1.

59. Frost, Przystup, and Saunders, “China’s Rising Influence in Asia,” p. 1.

60. Martyn Davies, How China Delivers Development Assistance to Africa, Center for Chinese Studies, University of Stellenbosch, February 2008, p. 4.

61. Ibid.

62. Ibid., p. 5 .

63. Ibid. The author has traveled to Ghana three times in 6 months and can vouch for this statement. The Chinese are everywhere in Ghana. Interestingly, the Chinese were looked on favorably by the Ghanaians in the early stages of China's investment interest. However, because the Chinese are now substituting Chinese labor for local labor, most of the locals are beginning to doubt Chinese sincerity and intentions.

64. Steven F. Jackson, "Chinese Official Development Assistance in Africa: New Money, Old Themes," unpublished paper presented to the International Studies Association annual meeting in San Francisco, California, March 2008.

65. Hilary Andersson, "China 'is Fueling War in Darfur” BBC News, 13 July 2008. Available at http://news.bbc.co.uk/2/hi/africa/7503428.stm (accessed May 2009).

66. Ibid.

67. Ibid.

68. Jim Yardley, "China Defends Sudan Policy and Criticizes Olympics Tie-In," The New York Times, 6 March 2008. Available at www.nytimes.com/2008/03/08/ world/asia/08darfur.html (accessed May 2009).

69. Ibid.

70. Robert G. Louis, "Professional Development of Special Forces Captains," unpublished paper, Carlisle Pennsylvania, 2002, p. 3. See also Department of the Army Pamphlet 600-3, Commissioned Officer Development and Career Management (Washington, DC: 11 December 2007), p. 175.

71. Ibid., p. 9. 
72. Multiple conversations with the late General (Ret.) Wayne Downing at the Combating Training Center, U.S. Military Academy, West Point, February 2003 to May 2005.

73. Comment made by Admiral Eric Olson at the Special Operations Education Conference, Hurlburt Field, Florida, June 2008.

74. U.S. Army Special Warfare Center and School "Leader Development Model," 17 August 2008. OPR: AOJK-DTD-TD. pp. 7-18.

75. Ibid.

76. There are several variations of this quote. This is the one I have used in my writings on Chinese security, foreign policy, and strategy issues.

77. For a full explanation, see "Institutional Mechanisms Fail to Address Recurrent Violence and Displacement," Internal Displacement Monitoring Centre, 29 October 2007. Available at: www.internal-displacement.org/8025708F004CE90B/(http Countries)/19D5FDB3E4AF4D1D802570A7004B613E?OpenDocument (accessed May 2009).

78. Comment attributed to Michael Sheehan. This was related to me in a tutorial the day I landed in Mogadishu as part of a team to support the Special Representative to the Secretary General in Somalia in 1993.

79. Under MG Dave Baratto, the author has had responsibility for language training at the Special Warfare Center when he commanded the 3rd Battalion of the 1st Special Warfare Training Group from 1990-1992. In September 2007, the author interviewed the 3rd Battalion commander about changes to the Special Forces Language curriculum, which is now taught in increments throughout the entire Special Forces Qualification Course instead of in a 6-month block at the end of the Q Course as it previously was.

80. Robert Hercuse, interview and demonstration. 13 May 2008. (Was a radio show report in New South Wales, Australia.)

81. This statistic was prevalent during my tenure as the commander of the 3rd Battalion, 1st Special Warfare Training Group in 1990-1992. In that position, I was responsible for the Special Forces Language School.

82. For example, one such Chinese-language station is channel 25, or CCTV, in Abuja, Nigeria.

83. Russell D. Howard, "Intelligence in Denied Areas," Joint Special Operations Report 7-10, December 2007, p. 25.

84. Roy Allgauer, "The U.S. Military and NGO Relationship During Post-Conflict Humanitarian Emergency Operations: How Can the U.S. Military Improve It?” unpublished paper, U.S. Naval War College, 16 May 2006, p. 1.

85. Discussions with colleagues at The Fletcher School of Law and Diplomacy, Tufts University, 14 October 2006.

86. Brian Maher (JSOU president), “The Way Forward," Spring 2008, p. 51.

87. The author is most familiar with The Fletcher School's existing program and the University of Montana's planned program due to his background as a pro- 
gram director and adjunct faculty member at The Fletcher School and his current position on the faculty at the University of Montana.

88. See the course description in the University of North Carolina's Curriculum in Peace, War, and Defense online course catalog; available at www.unc.edu/depts/ pwad/courses.html (accessed May 2009).

89. Ibid.

90. Conversation with Dr. Kay Knickrehm, associate dean, School of Public and International Affairs, James Madison University, 13 August 2008 and further e-mail correspondence with Dr. Knickrehm on 6 October 2008.

91. J. Tennant, "Graduate program in interagency studies for SOF students attending Intermediate Level Education (ILE) and other courses at Fort Leavenworth," Concept Paper, 21 April 2008.

92. Phone conversation with Dr. Hy Rothstein, 6 October 2008. See also the Naval Postgraduate School's Academics Catalog Web site, available at www.nps.edu/ Academics/GeneralCatalog/414.htm\#0426 (accessed May 2009).

93. Ibid.

94. Discussions with Nicki Sass, GMAP Admissions officer, 2007-2008.

95. See the University of Norwich's Master of Arts in Diplomacy program Web site, available at www.graduate.norwich.edu/diplomacy/program_overview.php (accessed May 2009). The author also held multiple discussions with Peter Liotta, director of the Pell Center at Salve Regina University and member of the Norwich distance-learning faculty.

96. Ibid.

97. Ibid.

98. Dr. Terry Weidner, director of the Mansfield Center at the University of Montana, in an interview on 8 September 2009.

99. See Note 95.

100. Colonel Casey Wardynski, Office of Economic and Manpower Analysis, 12 June 2008. Figures are for 2007.

101. The statistical information provided for the previous paragraph and Table 1 were provided by Colonel Casey Wardynski, the director of the Army's Office of Economic Analysis (OEMA). The data was forwarded in July 2008 and reflects graduate degree statistics up through 30 September 2007.

102. Even before Iraq and Afghanistan deployments, it was difficult for Special Forces officers (and noncommissioned officers) to take advantage of on post-graduate degree programs because of demanding TDY schedules. That was the author's experience while commanding the 1st Special Forces Groups.

103. This is not an inference that non-Special Forces officers do not deploy. Many of the author's former non-Special Forces West Point students are working on their fourth combat tour. However, rotation schedules, TDY demands, and the added $\mathrm{Q}$ course requirement for Special Forces officers limit their "discretionary" time opportunities as compared to their non-Special Forces counterparts. 
104. DA Pamphlet 600-3, “Officer Personnel Management," December 2007, p. 164.

105. Jeannie L. Johnson, "Strategic Culture: Refining the Theoretical Construct," Defense Threat Reduction Agency, 31 October 2006, p. 16.

106. Ibid.

107. This is a "take-away" from a briefing given to BG David Repass, commander of U.S. Special Forces Command, on 3 November 2008. 
